\title{
Effects of Changes in Arctic Lake and River Ice
}

\author{
Terry Prowse, Knut Alfredsen, Spyros Beltaos, Barrie R. Bonsal, \\ William B. Bowden, Claude R. Duguay, Atte Korhola, Jim McNamara, \\ Warwick F. Vincent, Valery Vuglinsky, Katey M. Walter Anthony, \\ Gesa A. Weyhenmeyer
}

\begin{abstract}
Climatic changes to freshwater ice in the Arctic are projected to produce a variety of effects on hydrologic, ecological, and socio-economic systems. Key hydrologic impacts include changes to low flows, lake evaporation regimes and water levels, and river-ice break-up severity and timing. The latter are of particular concern because of their effect on river geomorphology, vegetation, sediment and nutrient fluxes, and sustainment of riparian aquatic habitats. Changes in ice phenology will affect a wide range of related biological aspects of seasonality. Some changes are likely to be gradual, but others could be more abrupt as systems cross critical ecological thresholds. Transportation and hydroelectric production are two of the socio-economic sectors most vulnerable to change in freshwater-ice regimes. Ice roads will require expensive on-land replacements while hydroelectric operations will both benefit and be challenged. The ability to undertake some traditional harvesting methods will also be affected.
\end{abstract}

Keywords River ice $\cdot$ Lake ice Climate $\cdot$ Arctic . Aquatic ecology $\cdot$ Northern development

\section{INTRODUCTION}

This manuscript is the third of three papers in this journal special issue (Callaghan et al. 2011) assessing the state and fate of freshwater ice in the Arctic. The material originates from the results of an international assessment of arctic lake and river ice conducted by the Arctic Monitoring and Assessment Program, SWIPA project (Snow, Water, Ice,

Electronic supplementary material The online version of this article (doi:10.1007/s13280-011-0217-6) contains supplementary material, which is available to authorized users.
Permafrost in the Arctic) (AMAP 2011). The first introductory manuscript (Prowse et al. 2011a [this issue]) provides details about its overall spatial extent, state of observation programs, and climatic role, while the second reviews the past and future changes in observed ice conditions and includes extensive On-line Supplementary Material about paleo-historical changes (Prowse et al. $2011 \mathrm{~b}$ [this issue]). This article focuses on some of the key effects that changes in lake and river ice have had, or are projected to have, on freshwater ecological and socioeconomic systems. Most of these, however, are also influenced by hydrologic impacts that are directly produced by changes in freshwater ice. The details and diversity of these are reviewed in the On-line Supplementary Material for this manuscript, which also contains a review of the chemical effects of changes to lentic and lotic ecosystems.

\section{ECOLOGICAL EFFECTS}

\section{Lentic Ecosystems}

The most critical climate thresholds for lake ecosystems are those affecting the area and volume of standing water, while changes in the ice regime and surrounding catchments can have major impacts on aquatic habitat size and integrity and geochemical inputs (Vincent and LaybournParry 2008). In general, such changes are most apparent for relatively shallow systems, in some cases leading to their complete disappearance. For example, permafrost thawing and the production of surface to groundwater flow systems have been responsible for the elimination of many small water bodies in Siberia (Smith et al. 2005). Similarly, increased evaporative losses related to decreases in icecover duration can lead to the loss of aquatic habitats, such 
as the drying of High Arctic ponds (Smol and Douglas 2007). In other regions, the accelerated thawing of permafrost over the past 50 years has created new basins for lakes and ponds, and increased development of shallowwater ecosystems (Payette et al. 2004; Walter et al. 2006).

The surface area and depth of lakes and ponds affect ice formation. For example, lakes shallower than about 2-m regularly freeze to the bottom (i.e., lake ice typically forms to 2-m depth in most regions of the Arctic). Two possible consequences exist if the ice regime is altered. If winters become locally warmer and precipitation (as snow) increases, then ice thickness will decrease. Consequently, habitable depths for shallow lakes and ponds on tundra previously frozen to the bottom are likely to increase and enhanced invertebrate and/or fish survival may be possible. Another potential consequence will be a more rapid ice loss the following spring (related to a thinner ice cover) leading to an earlier open-water season and an earlier start to spring and summer production.

For some polar lakes, ice dams from glaciers or ice shelves are the primary structures retaining the freshwater, and their collapse can result in catastrophic drainage (e.g., Mueller et al. 2003; Vincent et al. 2009). The seasonal production and melting of ice dams along the Arctic coastline are responsible for stamukhi lakes, which are important biogeochemical processing sites for large river inputs to the Arctic Ocean that may be subject to climaterelated impacts in the future (Galand et al. 2008).

Climate change is resulting in earlier dates of ice breakup (see Prowse et al. 2011b) and, for extreme High Arctic lakes, is causing the onset of summer ice-free conditions in lakes that in the past have been covered by perennial ice (Mueller et al. 2009; Vincent et al. 2009). Both snow and ice affect underwater ultraviolet (UV) radiation and photosynthetically available radiation. Model results suggested that reductions in snow cover would have a much greater effect on underwater UV exposure than moderate stratospheric ozone depletion (Vincent et al. 2007). In some icecovered lakes, much of the photosynthetic production in the water column is associated with a deep maximum of phytoplankton or photosynthetic sulfur bacteria. In one high-Arctic lake, for example, past changes in planktonic production as inferred from pigment concentrations in sediments have been attributed to climate-related changes in snow and ice cover (Antoniades et al. 2009).

For some lakes, the loss of ice can result in the loss of vertical habitat structure and cooling (Vincent et al. 2008a). A further evaluation of potential future changes in water temperature and thermal lake structure across the Northern Hemisphere was conducted by Dibike et al. (2011). For example, Fig. 1 shows the mean annual cycle of simulated water-temperature profiles in hypothetical lakes of $20-\mathrm{m}$ depth along longitudinal transects at $105^{\circ} \mathrm{W}$ and $90^{\circ} \mathrm{E}$, representing cross-sections through central continental areas of North America and Asia, respectively. Results suggest that future warming will result in an overall increase in water temperature, with summer stratification starting earlier and extending later into the year.

Warming of the underlying water column by radiation is controlled to varying degrees by the thickness and composition of the snow- and lake-ice cover; white and black ice, for example, have different levels of albedo and transmissivity. In combination with water color and transparency, this affects heating rates, depths and mixing (e.g., Cahill et al. 2005). Earlier thinning and loss of ice cover also contribute to enhanced heating of the water column, which ultimately sets conditions for earlier and shallower development of the thermocline by increasing temperature differentials between surface and bottom waters. Longer open-water periods can further enhance overall lake warming, the combined effect being to drive high-latitude lakes from monomixis to dimixis. This threshold effect, as a result of water temperature rising above the point of maximum density $\left(\sim 4^{\circ} \mathrm{C}\right)$, can affect many other habitat properties, such as nutrient regimes and water-column oxygenation.

Ice is a key physical parameter that both structures and regulates abiotic and biotic processes within Arctic aquatic ecosystems. Biotic responses are induced at an individual, population, or community level depending upon the nature (rate, direction, magnitude, spatial scale) of abiotic change. Accordingly, shifts in ice characteristics will cascade through ecosystems, resulting in widespread alterations. For example, in addition to effects at the individual and population levels, changes in ice will affect trophic coupling, potentially engender mismatches between physical drivers and biotic responses, and affect phenological events such as the timing of key system transitions and life history shifts in biota.

In the case of photosynthetic production in lakes, the duration of open water is particularly critical. For example, the 250 000-year paleolimnological record from Lake El'gygytgyn, an ancient crater lake in the Siberian Arctic, showed that periods of the highest primary productivity were associated with warm, ice-free summer conditions, while the lowest rates were associated with periods of perennial ice coated by snow (Melles et al. 2007). In addition to improved light conditions for photosynthesis, measured levels of primary productivity could be further compounded by alterations in other environmental factors, such as increased wind-induced mixing and entrainment of nutrients into the euphotic zone, and catchment geochemical inputs.

Changes in the timing of freeze-up and break-up on lakes will also affect important biological aspects of seasonality. For example, the seasonal succession of plankton has been well described in many northern temperate lakes and is 
(a) Mean Daily Lake Water Temperature Profiles Along $105^{\circ} \mathrm{W}$ Longitude, 1960-1999

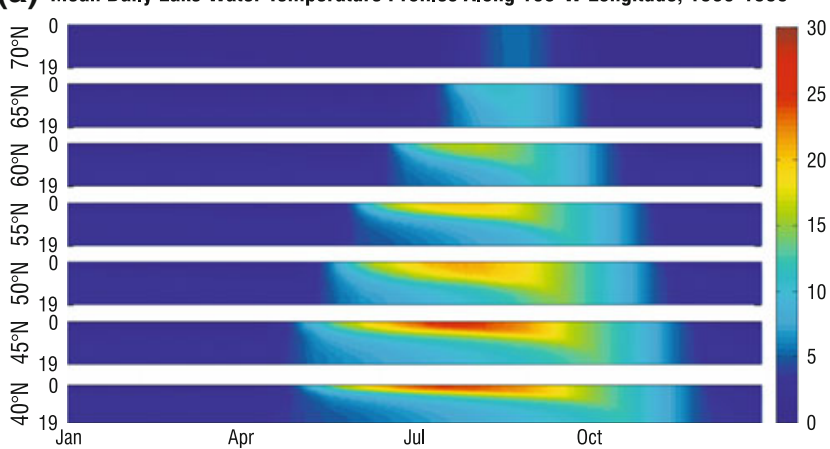

(C) Mean Daily Lake Water Temperature Profiles Along $105^{\circ} \mathrm{W}$ Longitude, 2040-2079

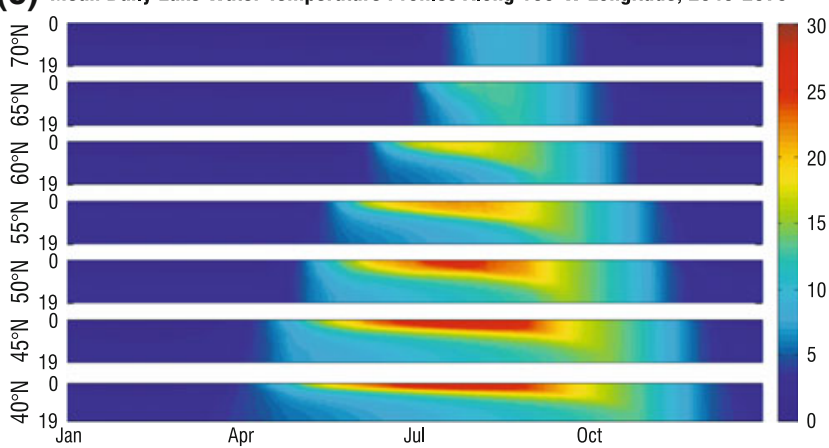

(e) Change in Mean Daily Lake Water Temperature Profiles Along $105^{\circ} \mathrm{W}$ Longitude,

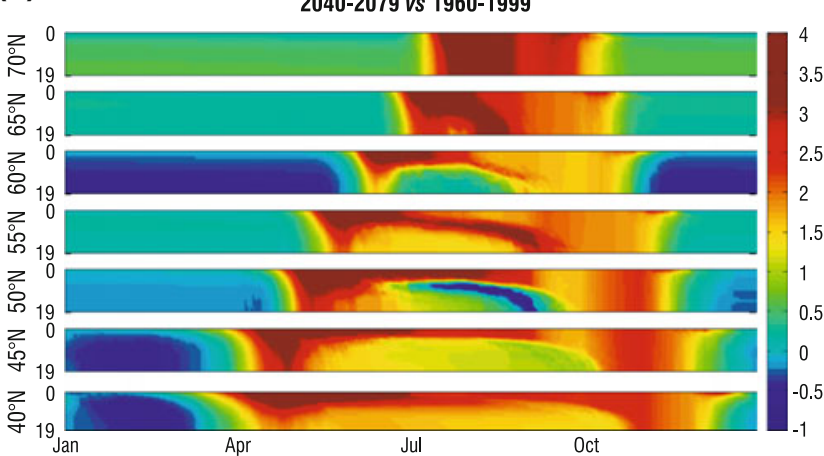

Fig. 1 Modeled mean annual cycle of daily profiles in water temperature in lakes during 1960-1999 (a, b) and 2040-2079 (c, d) as well as the corresponding change between these periods

strongly coupled with the freeze-up and break-up of ice cover and summer thermal stratification (Sommer 1989). A variety of structural and functional ecosystem changes in such lakes have been coupled to the changes in seasonality, in particular to an earlier ice break-up and an earlier onset of stratification, and provide insights into how Arctic lakes may respond to ice-induced changes in seasonality. One of the most obvious effects of an earlier timing of temperate lake-ice break-up has been an advanced spring phytoplankton bloom (e.g., Peeters et al. 2007) often resulting in an earlier zooplankton biomass peak. However, a synchronous response to these higher spring temperatures is usually restricted to fast-growing plankton, while slow-growing (b) Mean Daily Lake Water Temperature Profiles Along $90^{\circ}$ E Longitude, 1960-1999

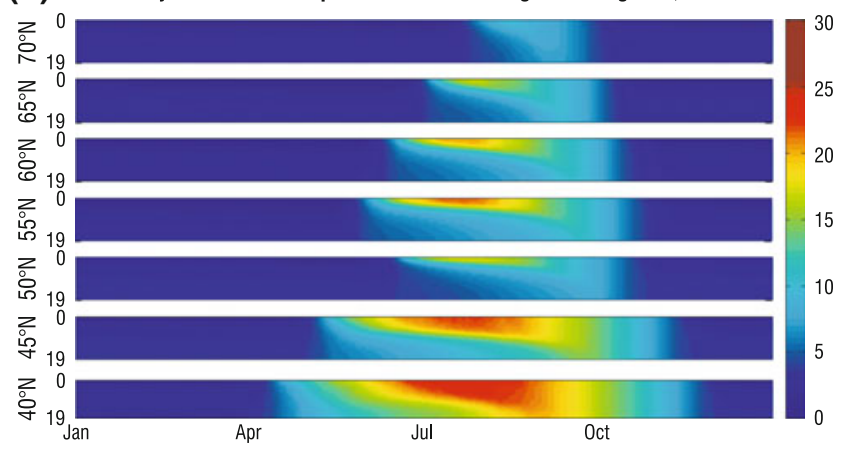

(d) Mean Daily Lake Water Temperature Profiles Along 90 E Longitude, 2040-2079

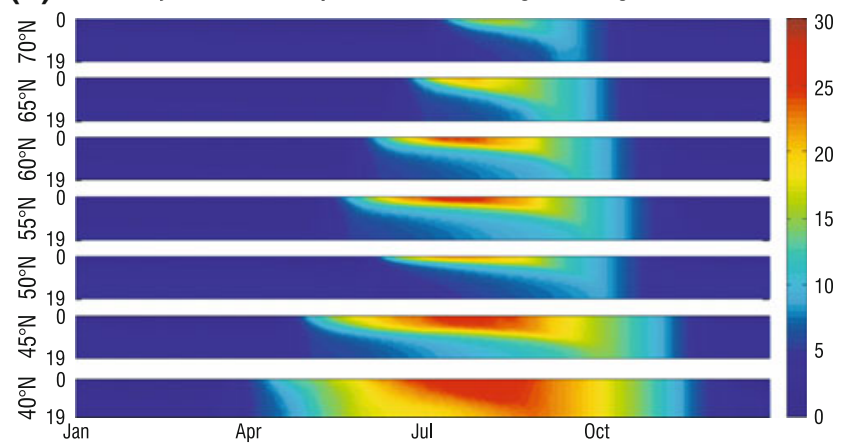

(f) Change in Mean Daily Lake Water Temperature Profiles Along $90^{\circ} \mathrm{E}$ Longitude,

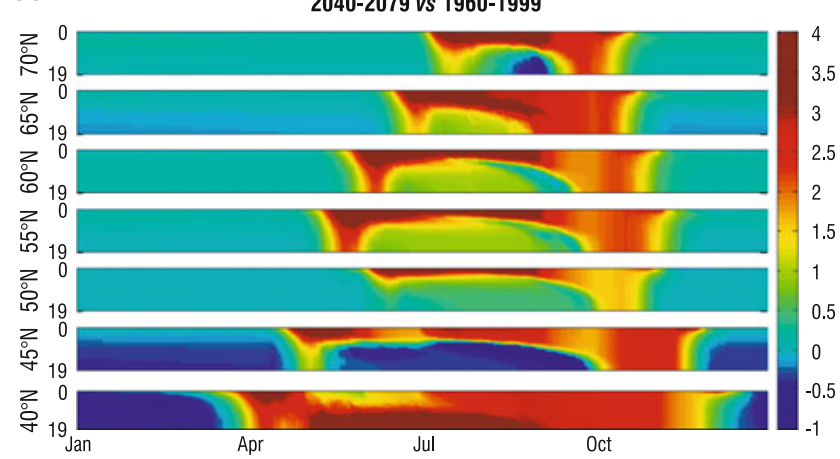

(e, f) at $5^{\circ}$ latitude intervals along example longitudinal transects on (a, c, e) $105^{\circ} \mathrm{W}$ and $(\mathbf{b}, \mathbf{d}, \mathbf{f}) 90^{\circ}$ E. Source Dibike et al. (2011)

species with complex life histories show species-specific responses (e.g., Adrian et al. 2006).

Changes in lake-ice regimes will have significant impacts on primary productivity and related trophic relationships in Arctic lakes. For example, increased temperatures and stratification associated with decreases in ice cover, accompanied by larger nutrient inputs, may favor the development of certain phytoplankton. In the case of noxious blooms of cyanobacteria, this could be a significant concern. Seasonality of the plankton is also likely to be affected by temporal changes in ice coverage given that planktonic flagellates have been observed to be abundant below the ice in Arctic lakes, whereas diatoms appear once 
the ice has gone. In general, although photosynthesis does take place beneath an ice cover, it is expected that primary production will increase with decreased ice thickness and snow cover (e.g., Vincent et al. 2008b). However, in Arctic regions projected to experience increases in surface accumulations of snow and/or the formation of white ice, underice plankton abundance could be negatively affected. Such changes in snow and white-ice coverage are also likely to affect levels of secondary productivity. Fish production in northern alpine lakes, for example, has been linked to snow depth (Borgstrøm and Museth 2005; Prowse et al. 2007).

Changes in water-column stratification associated with increased duration of open water can potentially result in the loss of some species and the establishment of others. By contrast, increased open water can allow the development of new trophic levels and even the establishment of aquatic bird species (Vincent et al. 2009). Warmer, more nutrientrich dimictic conditions may also favor cladocerans (Sorvari et al. 2002). Importantly, this could result in increased bioaccumulation of methylmercury relative to copepoddominated zooplankton communities (Chételat and Amyot 2009), with the potential for increased mercury transfer to fish and humans, although effects of biodilution may counteract this effect (Gantner et al. 2010).

Depending upon latitude, as well as specific lake characteristics, early thermocline development will profoundly alter lake ecosystems as well as the cold-water fish species present. Using lake trout in North America with summer temperature preferences of $10-12^{\circ} \mathrm{C}$ as an example, under climate warming southern boreal lakes will experience earlier and perhaps deeper thermocline formation than at present. Accordingly, the metalimnion (middle layer of a thermally stratified lake) and hypolimnion (lower layer of a thermally stratified lake) volumes will be smaller. These areas are used as a summer thermal refuge by lake trout (Salvelinus namaycush) at southern latitudes to escape epilimnion (upper mixed layer of a lake) temperatures of more than $12^{\circ} \mathrm{C}$; thus, smaller volumes of preferred habitat will lead to stress for individuals. At least over the near future, suitable thermal habitats for lake trout in Arctic lakes are likely to remain similar to those at present or increase in volume, thus promoting lake trout growth (provided that all other factors are equal).

The effects of wind are a complicating factor in ice dynamics and thermal structure affecting habitats. Earlier ice loss results in larger fetches being open earlier and longer. Wind-driven mixing of surface waters will almost certainly interact with heating to complicate thermocline development and depth; however, the nature of such effects remains unclear. Given that lake trout are generally longlived, such climate change signals may not be readily discernible within the populations. Moreover, decreased occurrences of winter fish kills due to oxygen depletion events will generally be an additional effect of reduced icecover duration (Stefan and Fang 1997). However, the significance of this is likely to vary by latitude and lake characteristics.

Ice cover also affects the migration and dispersal of aquatic organisms. A small number of Arctic lakes are permanently ice-covered (e.g., Vincent et al. 2008a) and their summer melt-out is typically restricted to a narrow moat. This greatly limits the wind-induced mixing and the presence of some biota. Increased melting of ice and snow in both the catchment and lakes in a warmer climate may result in an increased overflow and, consequently, a greater hydrological connectivity between the lakes (Kusumastuti et al. 2008).

\section{Lotic Ecosystems}

In Arctic rivers, ice is important in defining the in-stream habitat for fish, invertebrates, and aquatic plants. Through the modifications of ice regimes, climate change will have a profound influence on the behavior and biological response of stream biota (Huusko et al. 2007) and, therefore, will play a central role in their growth, survival and reproduction. Surface ice creates shelter habitats for fish in areas that are too exposed for use during open-water periods (Stickler et al. 2007; Linnansaari et al. 2009). A reduction in such ice shelter will, therefore, lead to a loss of suitable winter habitat during the period when the water temperature has not yet reached the level to cause changes in fish habitat use. In small and steep streams, winter formation of ice will define habitat availability and distribution independently of changes in discharge (Stickler et al. 2010). In such environments, a shorter ice season will influence habitat diversity. In addition, with future climate warming, an increased number of winter warm spells leading to mid-winter ice break-up may have a significant influence on habitat availability. Many Arctic rivers that currently have bed-fast ice, and thereby no available winter habitat, may shift into a regime with a floating ice cover. This will create new habitat for winter survival of species in these rivers.

Changes in ice cover can also have a direct impact on fish productivity and mortality. For example, for Atlantic salmon (Salmo salar) adapted to complete ice cover, removal of an ice cover has been shown to produce significant negative effects on their energy budget (Finstad et al. 2004a). Energy deficiency is important to winter survival, and a change in ice cover can reduce their ability to survive winter (Finstad et al. 2004b). Movement of salmonids to overwintering habitats mostly occurs prior to ice formation in rivers; however, local movements between habitats also occur after ice formation (Jakober et al. 1998; Linnansaari et al. 2009). Extensive anchor ice precludes 
access, whereas patchy anchor ice and ice-covered areas appear to be preferred (Linnansaari et al. 2009). Accordingly, reduced ice cover or duration on river systems is likely to result in a tradeoff between increased habitat (or access to such) with that habitat being less preferred due to lack of surface ice cover. Access, primarily by migratory Anadromous salmonids, to key overwintering habitats may thus provide benefits to overall population survival and productivity.

Large-scale changes in ice-cover duration and break-up timing will alter flow regimes and thereby influence Arctic rivers as migratory routes, affecting the timing of fish runs or even the migration of large mammals such as caribou (Sharma et al. 2009). Changes in flow timing in spring will also impact conditions for fish out-migration (Reist et al. 2006a, b). The loss of an ice cover is likely to increase the risk of predation on stream-living animals from mammalian and avian predators due to the loss of critical in-stream shelter. Moreover, winter and related ice formation could act as a 'bottleneck' for survival of fish and invertebrates. Results reported by Huusko et al. (2007) suggest that the variability in creating such bottlenecks among rivers is highly context dependent and controlled by the life stage of the fish, local habitat, and the related type of ice regime. Overall, the large and complex scope of potential changes in future river-ice regimes will make predictions of future biological responses difficult, particularly considering the current rather limited knowledge of high-latitude lotic systems.

\section{River Delta Ecosystems}

A number of major river deltas are found along the Arctic coast, as well as on the rivers that drain into the Arctic
Ocean. It has been recognized for some time that the water budget and nutrient-sediment supply of delta riparian zones are heavily dependent on ice-jam floodwaters. The strength of this dependence has been reinforced by recent work on the Mackenzie River delta, which contains about 45000 riparian lakes. Specifically, decreases in the severity of river-ice break-up has lessened the flooding of high closure lakes, which has the potential to result in the loss of some of these water bodies and changes in the biogeochemical processing of river water by the floodplain ecosystem (Fig. 2) (Lesack and Marsh 2007). Future climate conditions that produce thinner ice and reduced spring runoff (due to a smaller winter snowpack) will lead to overall reductions in ice-jam flooding (Beltaos et al. 2006) and could increase the threat to the health of such riparian ecosystems.

Freshwater environments at the coast are also prone to the effects of changing ice conditions. In the High Arctic, for example, fjords can be blocked by thick multi-year sea ice and ancient ice shelves, resulting in an extensive layer of freshwater called an 'epishelf lake.' These environments are proving to host microbial ecosystems with diverse biological communities; however, they are extremely vulnerable to ongoing climate warming and the loss of ice. Observations along the northern coastline of Ellesmere Island, Canada, have shown that many of these unique ecosystems have been driven to extinction as a result of recent climate change, and that they are sensitive indicators of climate change (Veillette et al. 2008). Other icedependent freshwater lakes at the High Arctic coast are becoming inundated with seawater due to the loss of integrity of their retaining ice dams (e.g., Vincent et al. 2009), and the extensive, microbiologically rich ice-bound lakes on ice shelves are disappearing completely as a result of their melting and collapse (Mueller et al. 2008).

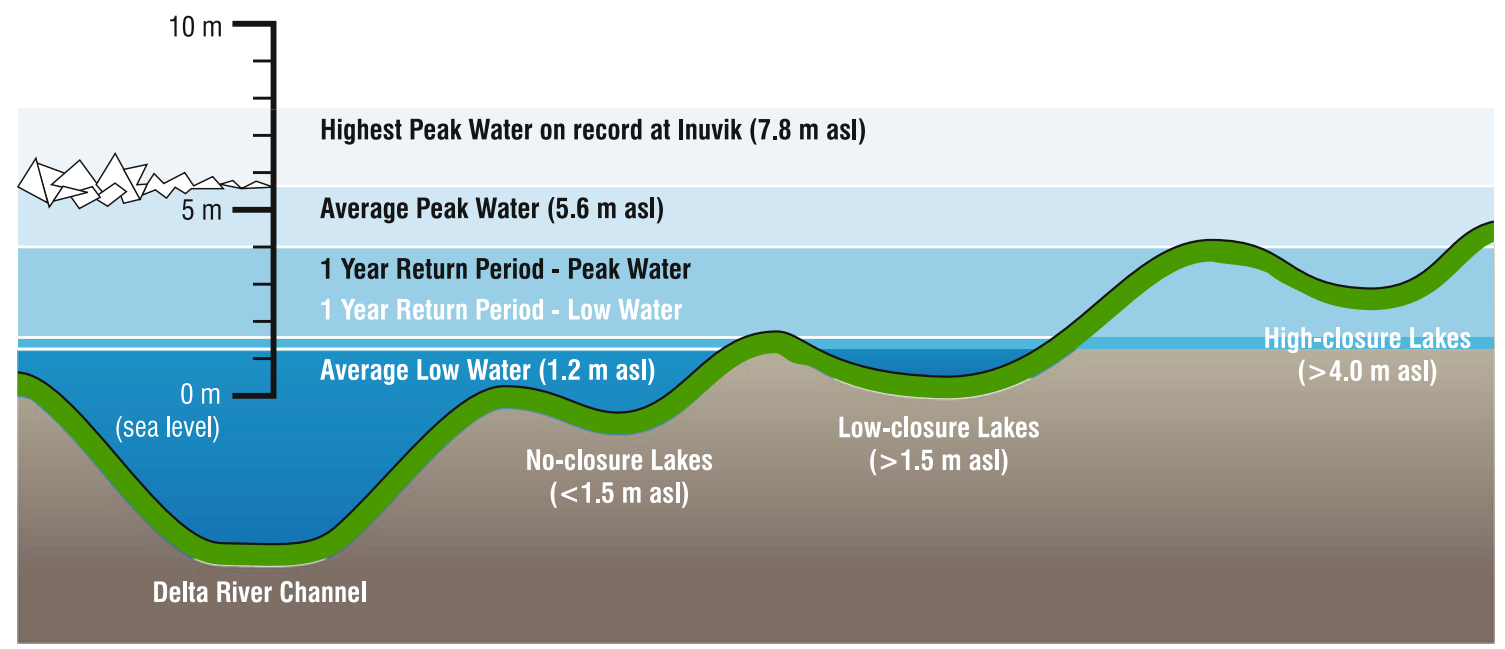

Fig. 2 Classification of lakes in the Mackenzie River delta according to the extent of their isolation from the river. Ice-jam floodwaters are responsible for flooding of the riparian lake systems more hydraulically unconnected to the main flow system. Modified from Emmerton et al. (2007) 


\section{SOCIO-ECONOMIC CONSEQUENCES AND ADAPTATION OPTIONS}

\section{Northern Infrastructure, Transportation, and Traditional Lifestyles}

Lake and river ice provide seasonal transportation platforms throughout the Arctic. Many northerners depend on this natural network for access to isolated communities, remote industrial developments and, hunting, fishing, herding and trapping areas, often in support of traditional subsistence-based lifestyles (e.g., Vuglinsky and Gronskaya 2006; Prowse et al. 2009). Changes in ice regimes, however, will make such access more uncertain and potentially hazardous and may reduce the ability to undertake some traditional harvesting methods. By contrast, any increase in the ice-free season will reduce the costs of ice breaking to maintain shipping routes, such as on the Yenisey River where nuclear-powered ice breakers are currently used.

Although scientific publications that explicitly detail the importance of ice roads to northern communities are rare (e.g., Ford et al. 2008), there are many accounts in the public press when such networks are affected by unseasonably warm weather. In one event reported by Carlson (2010), mild weather in March 2010 caused the province of Manitoba, Canada, to close a 2200-km winter road network composed of muskeg, lakes, and rivers. It had deteriorated to the point of stranding numerous freight haulers and local drivers, necessitating emergency evacuations. Typically, the road carries more than 2500 shipments each year to more than 30000 first nations people. In response to dwindling construction supplies, rising food and fuel prices, and a related rise in unemployment, First Nations Chiefs declared a state of emergency in 11 communities. Carlson (2010) also noted that because of deteriorating conditions, approximately $600 \mathrm{~km}$ of the winter road system have been relocated to land since 2001 (Government of Manitoba 2010) and spending on winter roads has tripled since 1999 (Government of Manitoba 2009).

Ice roads are also critical to the resupply of the complex of mining centers, which cannot use air access for the transport of heavy loads, fuel, and large equipment. One example is the $600-\mathrm{km}$ long Tibbitt to Contwoyto Winter Road in northern Canada, which travels over $495 \mathrm{~km}$ of frozen tundra, lakes, and rivers (Fig. 3). It has been estimated to contribute significantly to the territorial and national annual economies-approximately US $\$ 800$ million and US\$ 350 million, respectively, in 2001 but rising significantly with enhanced northern development (EBA Engineering Consultants 2001). A similar example is the 360-km long winter road in the Chukotka region of Russia constructed each winter from the ocean port Pevek to the
Kupol gold and silver mine at Bilibino (Noble 2009). In such cases, reductions in ice duration, thickness, or mechanical strength could have major implications for such remote developments. For some Arctic centers, changes in ice-related transport can have both positive and negative effects. In the case of Arkhangelsk on the Northern Dvina River, Russia, an increased shipping period and freight turnover from the inland navigation fleet would result from a decrease in ice duration, but, on the other hand, delays in the building of ice-road crossings would create substantial difficulties for local freight and public transportation (Ginzburg 1989).

Initially, adaptation to the reduction in the size of maximum loads that can be safely transported on northern ice roads could involve (i) modifications to techniques involved in ice-road construction; or (ii) modification of transport schedules to concentrate more on the coldest part of winter (Prowse et al. 2009). Continued warming will preclude ice roads as a major form of northern transportation, and there will be a need for alternative forms of transportation. In cases where an open-water network is feasible, transport by barge could be possible. For landlocked locations, however, the only viable option for heavy-load transport will be the construction of land-based road or rail networks. The initial capital costs of these, however, are likely to be enormous, especially where they must pass over terrain that is also projected to experience significant permafrost thaw and subsidence from climate change.

\section{Hydroelectric Power}

Production of hydroelectric power is important in several Arctic countries, the operations of which are seasonally constrained by the effects of river ice. At present, the total installed capacity in the Arctic countries (2006 data) is approximately $80 \mathrm{GW}$ (Fig. 4), but for many areas, unregulated large northern rivers still hold vast potential (Prowse 2009). With the future projections of inflow, this potential will probably increase for most of the Arctic region (Hamududu and Killingtveit 2010). Changes in ice conditions can affect hydroelectric operations in a number of ways, both positively and negatively. For example, the estimation of ice loads on facilities such as dams, intakes, outlets, and gates is important both for engineering design and operations (Comfort et al. 2003). A shorter ice season and thinner ice cover could reduce the static ice loads on dams, but on the other hand, a more unstable winter with mechanical ice break-ups could increase the dynamic loads on in-channel facilities. More unstable winter conditions could also lead to weakened ice and consequently a reduction in ice loads. 


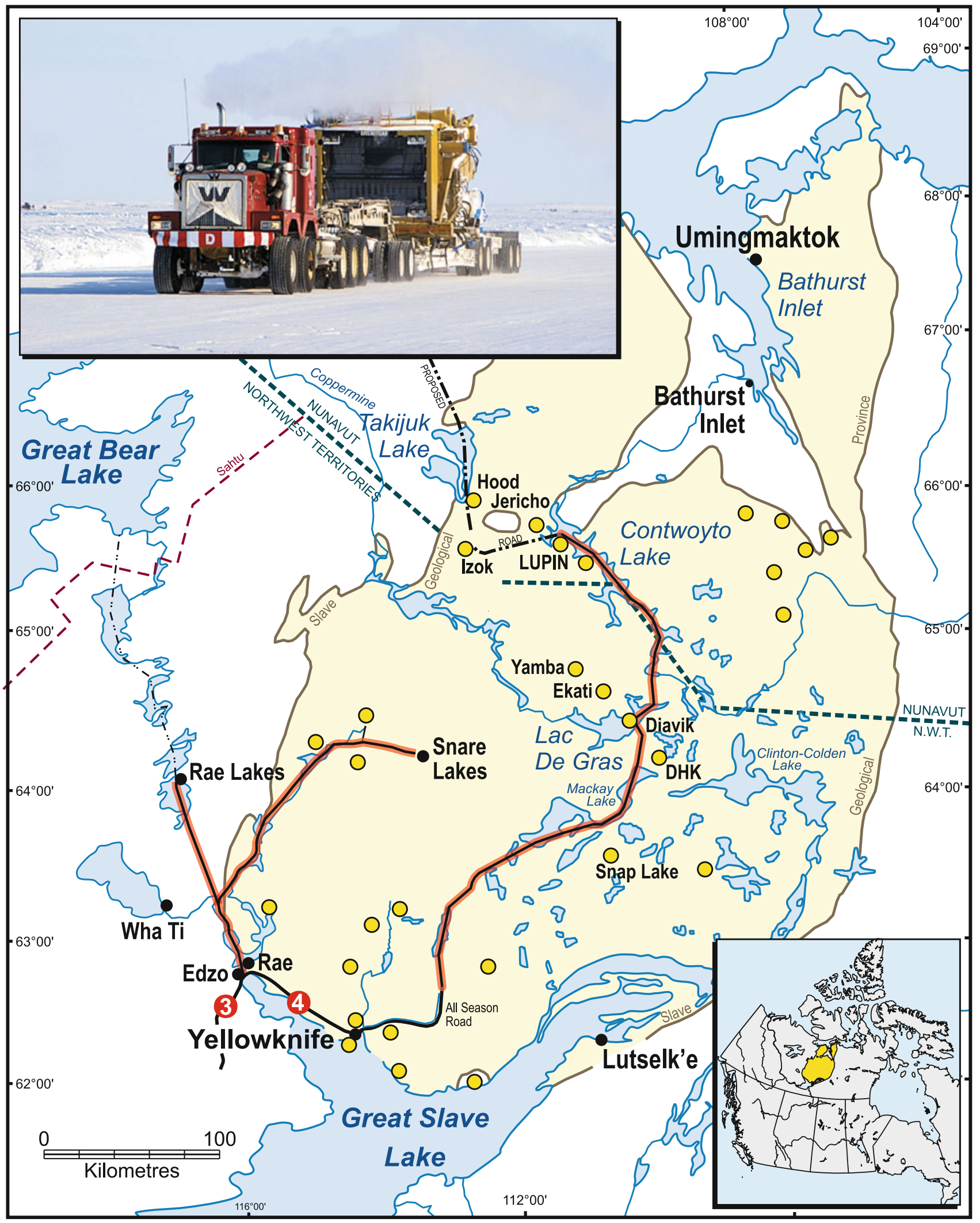

Fig. 3 Example of large loads transported on the Tibbitt to Contwoyto Winter Road in northern Canada, which is composed of many long reaches across frozen tundra, lakes, and rivers. Photo courtesy of Joint Venture Management Committee, partnership between DeBeers Canada, Inc.; BHP Billiton, Ltd; and Diavik Diamond Mines, Inc 


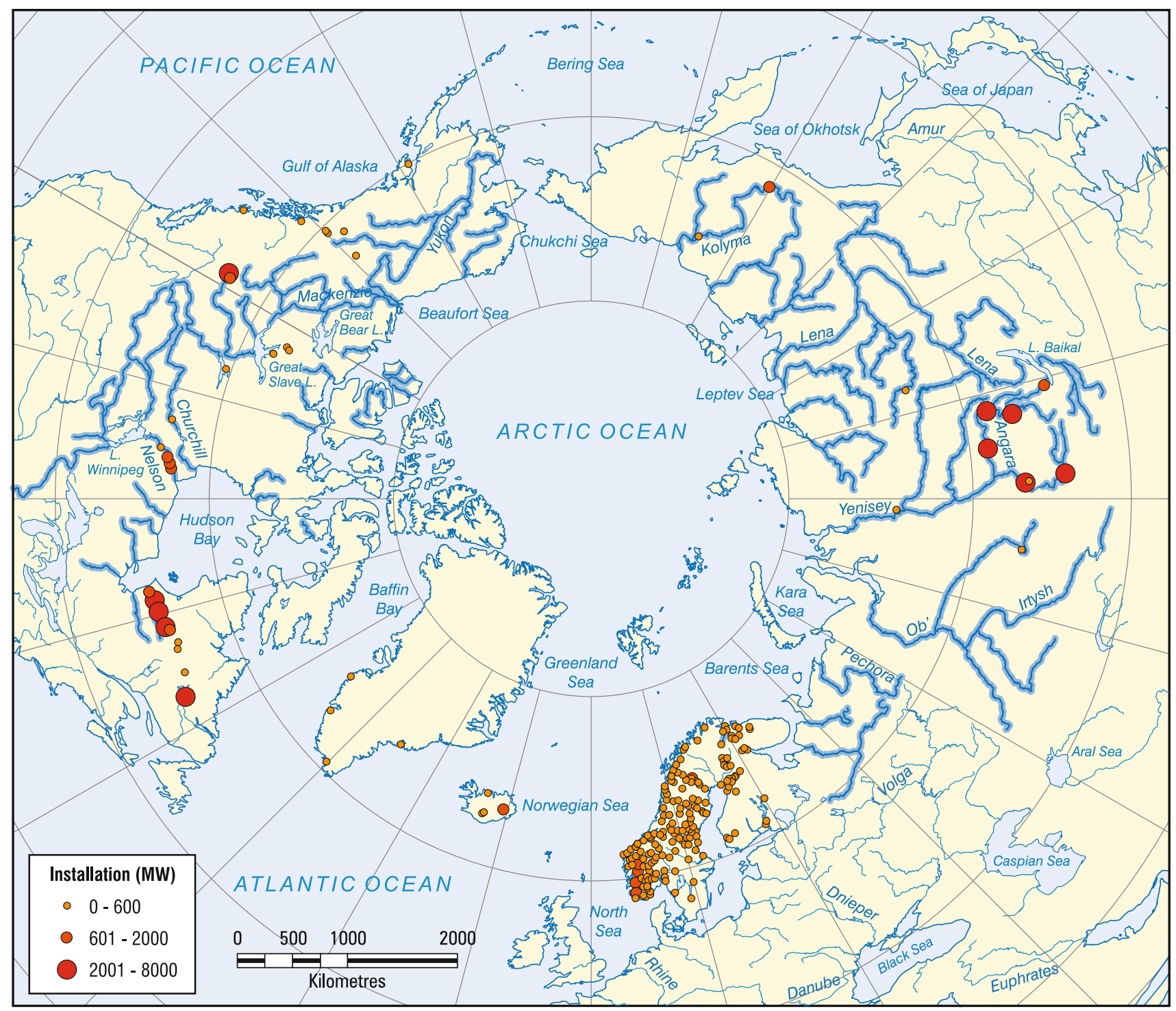

Fig. 4 Location and size of major hydroelectric facilities located in ice-dominated river regimes of the circumpolar North. All such stations will require major modifications to current operational regimes and possibly infrastructure modifications based on projected changes to freshwater ice regimes (due to data availability, the figure may not show all existing plants). Source K. Alfredsen, Norwegian University of Science and Technology

reaches as inflowing production water is forced to bypass intakes. Reaches downstream of intakes are usually characterized by early ice formation and low winter-flow, and sudden releases of water may initiate mechanical breakups, resulting in ice jamming and erosion damage. In a future with less stable conditions and a longer freeze-up period, this problem may increase in some areas, but it is also likely that it will be reduced in the most southern, temperate river systems. Second, in regions where there is an increase in the intensity or frequency of mid-winter warming spells and, therefore, an increased potential for mechanical winter break-ups, clogging of intakes by drifting ice will cause a loss of water, thus decreasing could also initiate ice problems in downstream river 
production. This will be a problem particularly for secondary intakes used in water transfer in high-head systems (Lokna 2006). Monitoring and mitigation of such problems will be an issue especially for hydropower producers with remote facilities. Although hydropower dams are equipped with spillways to pass floods, the function of which is crucial to dam safety, ice formation can have an impact on the capacity and functionality of these structures (Lia 1997). In a period with more frequent mid-winter ice break-ups, spillway functionality may be affected, particularly in spillway systems with tunnels or gates.

The strength of ice on hydropower impoundments is strongly influenced by reservoir operations such as the lowering of water levels during winter. In a future with shorter winters and a thinner ice cover, the safety of using reservoir ice for transportation may be compromised. However, such changes in reservoir ice conditions could also lead to some positive impacts for reservoir design and management. Future climate conditions will decrease this volume of inactive storage and reduce some of the current negative consequences, including (i) part of the storage volume being unavailable during winter when electricity demand is high; (ii) grounded ice having the same effect as an additional dead pool storage, forcing the design of larger and costlier structures; (iii) the immobilized water only becoming available at the end of winter when streamflows are large (and demand for electricity is low) thereby increasing flood risk and the probability of spilling; and (iv) grounded ice changing the effective storage curve during winter, which if unaccounted for in dam operations leads to suboptimal decisions (Seidou et al. 2007). Reductions in any or all of these will provide benefits to hydroelectric operations.

The importance of river ice on hydroelectric operations may also be indirectly affected by future energy adaptations. For example, a reduction in greenhouse gas emissions will require the production of more renewable energy and lead to the introduction of more non-storable energy sources. In such a system, load balancing is needed to maintain a continuous supply, and hydropower is ideally suited for this (e.g., Benitez et al. 2008). This will have implications for the operational strategies of hydropower producers toward a peaking schedule, and must be considered when impacts of changes in river ice are evaluated. Generally, peaking operation of hydropower plants in rivers is considered an environmental challenge, and peaking during the ice season further increases potential problems (Scruton et al. 2008). Balancing the variable production from non-storable renewables could lead to a less regular operation of the hydropower system, thereby increasing the potential problems linked to breakup and ice jamming in rivers downstream of hydropower outlets.

\section{CONCLUSIONS AND FUTURE RECOMMENDATIONS}

A cascading set of hydrological, ecological, and socioeconomic effects have been, or are projected to be, caused by climatic related changes to lake and river ice. Of particular concern to hydrologic regimes are alterations to river low flows, lake evaporation and water levels, and river-ice break-up severity and timing. River geomorphology, vegetation regimes, and nutrient/sediment fluxes that sustain aquatic ecosystems are particularly sensitive to changes in the latter. Changes in river ice are also likely to have wide-ranging effects (both positive and negative) on the behavior and biological response of stream biota. With respect to lakes, changes in the timing of freeze-up and break-up will affect a wide range of related biological aspects of seasonality. Some changes are likely to be gradual, but others are likely to be more abrupt as systems cross critical ecological thresholds. Once again, positive and negative effects are possible. Changes in ice-induced hydrological connectivity and lake stratification also could lead to the loss of some species and the establishment of others.

Transportation and hydroelectric production are the two socio-economic sectors most vulnerable to change in freshwater-ice regimes. Continued warming will preclude ice roads as a major form of northern transportation; alternative forms of transportation will therefore be needed, but the capital costs of these are likely to be enormous. Changes to ice regimes will also make the practice of some traditional subsistence-based lifestyles potentially hazardous and may reduce the ability to undertake some traditional harvesting methods. Hydroelectric operations will both benefit and be challenged by changes in river-ice conditions. Monitoring and mitigation of ice-related problems will be a particular issue for hydropower producers with remote facilities.

Advancing the understanding of climate-induced changes to Arctic freshwater ice and the subsequent effects will require improvements to monitoring, predictive modeling, and assessments of adaption options. Monitoring around the circumpolar North could be greatly assisted by a standardization of in situ observation methods to facilitate intercomparison of data. Given the remoteness of much of the high latitudes, a special focus should be placed on adopting remote sensing approaches to augment the in situ networks. To achieve improved prediction of river-ice regimes, advancements need to be made in integrated models that consider future combined changes to landscape hydrology, water-ice-air energy exchanges, in-stream hydraulics, and ice mechanics. Associated predictive modeling of lake- and river-ice systems should be expanded from primarily physical characteristics to include 
effects on lentic and lotic ecosystems. A number of "supersites" from representative regions should also be established around the circumpolar North for conducting long-term monitoring, intercomparison of observational techniques, and validation of modeling results. Given the importance of many ice-affected socio-economic sectors in the Arctic, key locations of such activities should be considered in the selection of such supersites. By doing so, it is likely to maximize the socio-economic benefits of conducting future freshwater ice and climate change research in the Arctic.

Acknowledgments The authors wish to thank the various national granting agencies that made this review possible, specifically including the Canadian Natural Sciences and Engineering Research Council, ArcticNet, and Environment Canada who helped directly support this publication. Also gratefully acknowledged are the efforts of the Arctic Monitoring and Assessment Program Secretariat in helping to produce the original SWIPA report and to the various contributing SWIPA chapter authors including: V. Buzin, Y. Dibike, N. Gantner, L. Hinzman, L. Lia, T. Ouarda, R. Pienitz, J. Reist, M. Stickler, J. Weckström, and F. Wrona.

\section{REFERENCES}

Adrian, R., S. Wilhelm, and D. Gerten. 2006. Life-history traits of lake plankton species may govern their phenological response to climate warming. Global Change Biology 12: 652-661.

Antoniades, D., J. Veillette, J.M. Martineau, C. Belzile, J. Tomkins, R. Pienitz, S. Lamoureux, and W.F. Vincent. 2009. Bacterial dominance of phototrophic communities in a High Arctic lake and its implications for paleoclimate analysis. Polar Science 3: 147-161.

AMAP. 2011. Snow, water, ice and permafrost in the Arctic (SWIPA). Oslo: Arctic Monitoring and Assessment Programme (AMAP).

Beltaos, S., and T. Prowse. 2009. River-ice hydrology in a shrinking cryosphere. Hydrological Processes 23: 122-144.

Beltaos, S., T. Prowse, B. Bonsal, R. MacKay, L. Romolo, A. Pietroniro, and B. Toth. 2006. Climatic effects on ice-jam flooding of the Peace-Athabasca delta. Hydrological Processes 20: 4031-4050.

Benitez, L.E., P.C. Benitez, and G.C. van Kooten. 2008. The economics of wind power with energy storage. Energy Economics 30: 1973-1989.

Borgstrøm, R., and J. Museth. 2005. Accumulated snow and summer temperature-critical factors for recruitment to high mountain populations of brown trout (Salmo trutta L.). Ecology of Freshwater Fish 14: 375-384.

Cahill, K.L., J.M. Gunn, and M.N. Futter. 2005. Modelling ice cover, timing of spring stratification, and end-of-season mixing depth in small Precambrian Shield lakes. Canadian Journal of Fisheries and Aquatic Sciences 62: 2134-2142.

Callaghan, T.V., M. Johansson, and T.D. Prowse eds. 2011. Arctic cryosphere-Changes and impacts, ed. T.V. Callaghan, M. Johansson, and T.D. Prowse. Ambio 40(S1). doi:10.1007/s13280011-0210-0.

Carlson, K.B. 2010. End of the roads. National Post (Newspaper, Canada)

Chételat, J., and M. Amyot. 2009. Elevated methylmercury in High Arctic Daphnia and the role of productivity in controlling their distribution. Global Change Biology 15: 706-718.
Comfort, G., Y. Gong, S. Singh, and R. Abdelnour. 2003. Static ice loads on dams. Canadian Journal of Civil Engineering 30: $42-68$.

Dibike, Y., T. Prowse, T. Saloranta, and R. Ahmed. 2011. Response of Northern hemisphere lake-ice cover and lake-water thermal structure patterns to a changing climate. Hydrological Processes 25: 2942-2953. doi:10.1002/hyp.8068.

EBA Engineering Consultants Ltd. 2001. Tibbitt to Contwoyto Winter Road: Project Description Report. EBA Engineering Consultants Ltd.

Emmerton, C.A., L.F.W. Lesack, and P. Marsh. 2007. Lake abundance, potential water storage, and habitat distribution in the Mackenzie River delta, western Canadian Arctic. Water Resources Research 43: W05419. doi:10.1029/2006WR005139.

Ettema, R., G. Kirkil, and S. Daly. 2009. Frazil ice concerns for channels, pump-lines, penstocks, siphons, and tunnels in mountainous regions. Cold Regions Science and Technology 55: 202-211.

Finstad, A.G., T. Forseth, T.F. Næsje, and O. Ugedal. 2004a. The importance of ice cover for energy turnover in juvenile Atlantic salmon. Journal of Animal Ecology 73: 959-966.

Finstad, A.G., O. Ugedal, T. Forseth, and T.F. Næsje. 2004b. Energyrelated juvenile winter mortality in a northern population of Atlantic salmon (Salmo salar). Canadian Journal of Fisheries and Aquatic Sciences 61: 2358-2368.

Ford, J.D., T. Pearce, J. Gilligan, B. Smit, and J. Oakes. 2008. Climate change and hazards associated with ice use in northern Canada. Arctic, Antarctic, and Alpine Research 40: 647-659.

Galand, P.E., C. Lovejoy, J. Pouliot, M.E. Garneau, and W.F. Vincent. 2008. Microbial community diversity and heterotrophic production in a coastal Arctic ecosystem: A stamukhi lake and its source waters. Limnology and Oceanography 53: 813-823.

Gantner, N., M. Power, D. Iqaluk, M. Meili, H. Borg, M. Sundbom, K. Solomon, G. Lawson, et al. 2010. Mercury concentrations in landlocked Arctic char (Salvelinus alpinus) from the Canadian High Arctic: part I-Insights from trophic relationships in 18 lakes. Environmental Toxicology and Chemistry 29: 621-632.

Ginzburg, B.M. 1989. Calculation of probabilistic characteristics of ice regime for Northern Siberia Rivers. Paper presented at Ice 1987. Proceedings of conferences and meetings on hydrotechnics. Methodological problems of northern hydrotechnical construction and questions of prolongation of the navigation season. pp. 80-85. Energoatomizdat (in Russian).

Government of Manitoba. 2009. Winter roads in Manitoba. http://www.gov.mb.ca/mit/winter/index. Accessed 22 Oct 2010.

Government of Manitoba. 2010. Winter road system closing as a result of melting conditions. http://news.gov.mb.ca/news/index. html?archive =2010-3-01\&item=7955. Accessed 22 Oct 2010.

Hamududu, B., and $\breve{A}$. Killingtveit. 2010. Estimating effects of climate change on global hydropower production. Paper presented at Hydropower '10. Sixth international conference on hydropower, pp. 1-13, February 1-3, in Troms $\varnothing$, Norway.

Huusko, A., L. Greenberg, M. Stickler, T. Linnansaari, M. Nykänen, T. Vehanen, S. Koljonen, P. Louhi, et al. 2007. Life in the ice lane: The winter ecology of stream salmonids. River Research and Applications 23: 469-491.

Jakober, M.J., T.E. McMahon, R.F. Thurow, and C.G. Clancy. 1998. Role of stream ice on fall and winter movements and habitat use by bull trout and cutthroat trout in Montana headwater streams. Transactions of the American Fisheries Society 127: 223-235.

Kusumastuti, D.I., M. Sivapalan, I. Struthers, and D.A. Reynolds. 2008. Thresholds in the storm response of a lake chain system and the occurrence and magnitude of lake overflows: implications for flood frequency. Advances in Water Resources 31: 1651-1661.

Lesack, L.F.W., and P. Marsh. 2007. Lengthening plus shortening of river-to-lake connection times in the Mackenzie River delta respectively via two global change mechanisms along the arctic 
coast. Geophysical Research Letters 34: L23404. doi: 10.1029/2007GL031656.

Lia, L. 1997. Ice in spillways in connection with dam safety. In Hydropower'97. Proceedings of the 3rd international conference, Trondheim, Norway, 30 June-2 July 1997, ed. Broch, E., D.K. Lysne, N. Flatab $\varnothing$ and E.Helland-Hansen. A.A. Rotterdam: Balkema.

Linnansaari, T., K. Alfredsen, M. Stickler, J.V. Arnekleiv, A. Harby, and R.A. Cunjak. 2009. Does ice matter? Site fidelity and movements by Atlantic salmon (Salmo salar L.) parr during winter in a substrate enhanced river reach. River Research and Applications 25: 773-787.

Lokna, A. 2006. The Bjoreio Brook inlet. Physical model studies for ice run and hydraulic capacities. MSc Thesis. D1-2006-07 Thesis. Department of Hydraulic and Environmental Engineering. Norwegian University of Science and Technology.

Melles, M., J. Brigham-Grette, O.Y. Glushkova, P.S. Minyuk, N.R. Nowaczyk, and H.W. Hubberten. 2007. Sedimentary geochemistry of core PG1351 from Lake El'gygytgyn—a sensitive record of climate variability in the East Siberian Arctic during the past three glacial-interglacial cycles. Journal of Paleolimnology 37: 89-104.

Mueller, D.R., W.F. Vincent, and M.O. Jeffries. 2003. Break-up of the largest Arctic ice shelf and associated loss of an epishelf lake. Geophysical Research Letters 30: 2031. doi:10.1029/2003 GL017931.

Mueller, D.R., L. Copland, A. Hamilton, and D. Stern. 2008. Examining Arctic ice shelves prior to the 2008 breakup. EOS. Transactions of the American Geophysical Union 89: 502-503.

Mueller, D.R., P. Van Hove, D. Antoniades, M.O. Jeffries, and W.F. Vincent. 2009. High Arctic lakes as sentinel ecosystems: cascading regime shifts in climate, ice cover, and mixing. Limnology and Oceanography 54: 2371-2385.

Noble, R.B. 2009. Beating tough odds on top of the world. Canadian Mining Journal 130: 14-15.

Payette, S., A. Delwaide, M. Caccianiga, and M. Beauchemin. 2004. Accelerated thawing of subarctic peatland permafrost over the last 50 years. Geophysical Research Letters 31: L18208. doi: 10.1029/2004GL020358.

Peeters, F., D. Straile, A. Lorke, and D.M. Livingstone. 2007. Earlier onset of the spring phytoplankton bloom in lakes of the temperate zone in a warmer climate. Global Change Biology 13: $1898-1909$.

Prowse, T.D. 2009. Preface Introduction: hydrologic effects of a shrinking cryosphere. Hydrological Processes 23: 1-6.

Prowse, T.D., B.R. Bonsal, C.R. Duguay, D.O. Hessen, and V.S. Vuglinsky. 2007. River and lake ice. Global outlook for ice \& snow. United Nations Environment Programme.

Prowse, T.D., C. Furgal, R. Chouinard, H. Melling, D. Milburn, and S.L. Smith. 2009. Implications of climate change for economic development in northern Canada: Energy, resource, and transportation sectors. Ambio 38: 272-281.

Prowse, T.D., K. Alfredsen, S. Beltaos, B.R. Bonsal, C. Duguay, A. Korhola, J. McNamara, W.F. Vincent, et al. 2011a. Arctic freshwater ice and its climatic role. In Arctic cryosphereChanges and impacts, ed. T.V. Callaghan, M. Johansson, and T.D. Prowse. Ambio 40(S1). doi:10.1007/s13280-011-0214-9.

Prowse, T.D., K. Alfredsen, S. Beltaos, B.R. Bonsal, C. Duguay, A. Korhola, J. McNamara, R. Pienitz, et al. 2011b. Past and future changes in Arctic lake and river ice. In Arctic cryosphereChanges and impacts, ed. T.V. Callaghan, M. Johansson, and T.D. Prowse. Ambio 40(S1). doi:10.1007/s13280-011-0216-7.

Reist, J.D., F.J. Wrona, T.D. Prowse, M. Power, J.B. Dempson, R.J. Beamish, J.R. King, T.J. Carmichael, et al. 2006a. General effects of climate change on Arctic fishes and fish populations. Ambio 35: 370-380.
Reist, J.D., F.J. Wrona, T.D. Prowse, M. Power, J.B. Dempson, J.R. King, and R.J. Beamish. 2006b. An overview of effects of climate change on selected Arctic freshwater and anadromous fishes. Ambio 35: 381-387.

Scruton, D.A., C. Pennell, L.M.N. Ollerhead, K. Alfredsen, M. Stickler, A. Harby, M. Robertson, K.D. Clarke, et al. 2008. A synopsis of 'hydropeaking' studies on the response of juvenile Atlantic salmon to experimental flow alteration. Hydrobiologia 609: 263-275.

Seidou, O., T. Ouarda, and L. Bilodeau. 2007. Reservoir storage loss due to grounded ice during winter operation. Journal of Hydrology 335: 15-24.

Sharma, S., S. Couturier, and S.D. Côté. 2009. Impacts of climate change on the seasonal distribution of migratory caribou. Global Change Biology 15: 2549-2562.

Sommer, U. 1989. The role of competition for resources in phytoplankton succession. In Plankton ecology-succession in plankton communities, ed. U. Sommer, 57-106. New York: Springer-Verlag.

Smith, L.C., Y. Sheng, G.M. MacDonald, and L.D. Hinzman. 2005. Disappearing Arctic lakes. Science 308: 1429.

Smol, J.P., and M.S.V. Douglas. 2007. Crossing the final ecological threshold in high Arctic ponds. Proceedings of the National Academy of Sciences of the United States of America 104: 12395-12397.

Sorvari, S., A. Korhola, and R. Thompson. 2002. Lake diatom response to recent Arctic warming in Finnish Lapland. Global Change Biology 8: 171-181.

Stefan, H.G., and X. Fang. 1997. Simulated climate change effects on ice and snow covers on lakes in a temperate region. Cold Regions Science and Technology 25: 137-152.

Stickler, M., K. Alfredsen, D.A. Scruton, C. Pennell, A. Harby, and F. Økland. 2007. Mid-winter activity and movement of Atlantic salmon parr during ice formation events in a Norwegian regulated river. Hydrobiologia 582: 81-89.

Stickler, M., K.T. Alfredsen, T. Linnansaari, and H.-P. Fjeldstad. 2010. The influence of dynamic ice formation on hydraulic heterogeneity in steep streams. River research and applications 26: 1187-1197.

Veillette, J., D.R. Mueller, D. Antoniades, and W.F. Vincent. 2008. Arctic epishelf lakes as sentinel ecosystems: Past, present and future. Journal of Geophysical Research-Biogeosciences 113: G04014. doi:10.1029/2008JG000730.

Vincent, W.F., and J. Laybourn-Parry. 2008. Polar lakes and riverslimnology of Arctic and Antarctic aquatic ecosystems. Oxford: Oxford University Press.

Vincent, W.F., M. Rautio, and R. Pienitz. 2007. Climate control of underwater UV exposure in polar and alpine aquatic ecosystems. In Arctic Alpine ecosystems and people in a changing environment, ed. Orbaek, J.B., R. Kallenborn, I. Tombre, E. Hegseth, A. Falk-Petersen, and A.H. Hoel, pp. 227-249. Berlin: Springer.

Vincent, A.C., D.R. Mueller, and W.F. Vincent. 2008a. Simulated heat storage in a perennially ice-covered high Arctic lake: Sensitivity to climate change. Journal of Geophysical ResearchOceans 113: C04036. doi:10.1029/2007JC004360.

Vincent, W.F., J.E. Hobbie, and J. Laybourn-Parry. 2008b. Introduction to the limnology of high latitude lake and river ecosystems. In Polar lakes and rivers-limnology of Arctic and Antarctic aquatic ecosystems, ed. Vincent, W.F., and J. Laybourn-Parry, pp. 1-23. Oxford, UK: Oxford University Press.

Vincent, W.F., L.G. Whyte, C. Lovejoy, C.W. Greer, I. Laurion, C.A. Suttle, J. Corbeil, and D.R. Mueller. 2009. Arctic microbial ecosystems and impacts of extreme warming during the International Polar Year. Polar Science 3: 171-180.

Vuglinsky, V.S., and T.P. Gronskaya. 2006. Changing of rivers and lakes ice regime within the Russian territory and their possible 
consequences for economy. Modern problems of hydrometeorology, 229-245. St. Petersburg: Asterion (in Russian).

Walter, K.M., S.A. Zimov, J.P. Chanton, D. Verbyla, and F.S. Chapin III. 2006. Methane bubbling from Siberian thaw lakes as a positive feedback to climate warming. Nature 443: 71-75.

\section{AUTHOR BIOGRAPHIES}

Terry Prowse $(\triangle)$ is a senior Research Scientist with Environment Canada and a Professor in the Department of Geography at the University of Victoria. His research focuses on the effects of climate variability and change on cold-regions hydrology, hydro-climatology, and hydro-ecology.

Address: Department of Geography, University of Victoria, Victoria, BC V8P 5C2, Canada.

e-mail: terry.prowse@ec.gc.ca

Knut Alfredsen is a Professor in hydrology at the Norwegian University of Science and Technology. His main research interests include river ice, cold climate eco-hydrology, and environmental impacts of hydropower.

Address: Department of Hydraulic and Environmental Engineering, NTNU, 7491 Trondheim, Norway.

e-mail: knut.alfredsen@ntnu.no

Spyros Beltaos is a senior Research Scientist at the National Water Research Institute of Environment Canada and an Adjunct Professor at the Department of Geography, University of Victoria. His research interests include hydroclimatic and ecological impacts of ice processes in northern rivers and deltas, with emphasis on breakup and ice jams.

Address: Aquatic Ecosystem Impacts Research Division, Environment Canada, National Water Research Institute, 867 Lakeshore Rd., Burlington, ON L7R 4A6, Canada.

e-mail: spyros.beltaos@ec.gc.ca

Barrie R. Bonsal is a Research Scientist with Environment Canada where he specializes in the assessment of past and projected future climatological impacts on the hydrology and ecology of Canada and the Northern Hemisphere.

Address: Environment Canada, National Hydrology Research Centre, 11 Innovation Blvd, Saskatoon, SK S7N 3H5, Canada.

e-mail: barrie.bonsal@ec.gc.ca

William B. Bowden is the Patrick Professor of Watershed Science and Planning in the Rubenstein School of Environment and Natural Resources at the University of Vermont, USA. His primary research interest is on interactions between hydrological and biogeochemical processes.

Address: Rubenstein School of Environment and Natural Resources, 304 Aiken Center, University of Vermont, Burlington, VT 05405 , USA.

e-mail: breck.bowden@uvm.edu

Claude R. Duguay is a Professor in the Department of Geography \& Environmental Management and Founding Director of the Interdisciplinary Centre on Climate Change at the University of Waterloo. His research interests include climate-lake interactions, remote sensing and numerical modeling of the cryosphere, and northern hydrology.

Address: Department of Geography \& Environmental Management, University of Waterloo, 200 University Avenue West, Waterloo, ON N2L 3G1, Canada.

e-mail: crduguay@uwaterloo.ca
Atte Korhola is a Professor of environmental change at the University of Helsinki and a member of the Environment Panel of the European Academies Science Advisory Council (EASAC). His specialist research interests include climate change and its ecological and societal impacts with particular reference to longer term environmental changes and northern regions.

Address: Department of Environmental Sciences, ECRU, University of Helsinki, P.O. Box 65 (Viikinkaari 1), 00014 Helsinki, Finland. e-mail: atte.korhola@helsinki.fi

Jim McNamara is a Professor of hydrology at Boise State University in Boise Idaho, USA. His research interests include interactions between catchment hydrologic, geomorphologic, and biologic processes in cold regions.

Address: Boise State University, 1910 University Dr., Boise, ID 83703, USA.

e-mail: jmcnamar@boisestate.edu

Warwick F. Vincent is a Professor of biology and Canada Research Chair at Laval University, Canada, where he is also director of the Centre d'études nordiques (CEN), an inter-interuniversity centre of excellence for research on northern ecosystems and geosystems. He works on the effects of environmental change on polar aquatic ecosystems.

Address: Département de Biologie \& Centre d'Études Nordiques (CEN), Laval University, Québec City, QC G1V 0A6, Canada.

e-mail: warwick.vincent@bio.ulaval.ca

Valery Vuglinsky is a Professor and Deputy Director for Science at the State Hydrological Institute in the Russian Federation; he is also Head of Hydrology Department at St. Petersburg State University. His main research interests include: water resources and water balance, hydrology of lakes and reservoirs, water resources inventory and hydroecology.

Address: State Hydrological Institute, 2nd Line 23, St. Petersburg 199053, Russian Federation.

e-mail:vvuglins@vv4218.spb.edu

Katey M. Walter Anthony is an Assistant Professor at the Environmental Research Center Institute of Northern Engineering and International Arctic Research Center at the University of Alaska. Her current research interests include: methane in the Arctic, lakes, permafrost/thermokarst and climate change.

Address: Water and Environmental Research Center, University of Alaska, 306 Tanana Loop, Fairbanks, AK 99775-5960, USA.

e-mail: kmwalteranthony@alaska.edu

Gesa A. Weyhenmeyer is an Associate Professor and Senior Lecturer at Uppsala University and the Swedish University of Agricultural Sciences. She is presently a Research Fellow Post at the Royal Swedish Academy of Sciences and focuses her research on global change impacts on aquatic ecosystems.

Address: Department of Ecology and Genetics/Limnology, Uppsala University, Norbyvägen 18D, 75236 Uppsala, Sweden.

e-mail: gesa.weyhenmeyer@ebc.uu.se 